\title{
Informal Entrepreneurship Education: Overview of the Russian Field
}

\author{
Pavel Sorokin \\ Associate Professor and Senior Research Fellow, psorokin@hse.ru \\ Alexander Povalko \\ Professor, apovalko@hse.ru \\ Yulia Vyatskaya \\ Expert and Research Assistant, yumatyunenko@hse.ru \\ Institute of Education, National Research University Higher School of Economics, 20, Myasnitskaya str., \\ Moscow 10100, Russian Federation
}

\begin{abstract}
$\mathrm{T}$ his article analyzes the informal sector of entrepreneurial education - free "open" educational projects at the federal level in the context of broader trends in the development of education and society, including education's 'unbundling. The search for information was carried out using the Internet, as a result, 45 initiatives were discovered. The results show that the sector of entrepreneurship education is broad, but there are a large number of areas for improvement, in which universities can play an

important role. In particular, this concerns elaborating and implementing a system for evaluating educational results, organizing monitoring of the effectiveness of such initiatives, including the analysis of success stories. In addition, a separate task is to expand the set of targeted programs for specific audiences (for example, unemployed), as well as to improve the content of such initiatives more deeply according to the specifics of the relevant target groups (for example, young mothers or older people).
\end{abstract}

Keywords: entrepreneurship; entrepreneurship education; non-formal education; open initiatives; 'unbundling' education; ecosystem of entrepreneurship education
Citation: Sorokin P., Povalko A., Vyatskaya Y. (2021) Informal Entrepreneurship Education: Overview of the Russian Field. Foresight and STI Governance, 15(4), 22-31. DOI: 10.17323/25002597.2021.4.22.31 


\section{Introduction}

The higher education sphere is in the process of a major "unbundling" [McCowan, 2017]. Along with the traditional "long" educational products (bachelor's, master's, and other programs) new learning formats such as massive open online courses (MOOCs) or full-time intensive courses are gaining importance [Ivancheva et al., 2020]. Such initiatives form the previously nonexistent "micro-degree" system, which became a key factor in labor market development [Kulik, 2018]. The unbundling of education is a part of the overall science and technology development trend, which among other things includes the emergence of Industry 4.0 and the accelerated digitization of the economy and other key areas of life. This transformation is associated with the emergence of educational ecosystems. No generally accepted definition of the latter has yet been suggested, but experts agree they should be seen as formal and additional education and training systems based on cutting-edge technologies, which take into account the geographical and infrastructural context. A wide range of stakeholders affect the educational process, representing the state, business, and non-profit sector among others, with different requirements for the quality of education and different criteria they apply to evaluate its results [Bandyopadhyay et al., 2021]. The emergence of ecosystems reflects a significant increase in the complexity of this area in recent years, including the university segment traditionally regarded as its core element [Brush, 2014]. Faced with the growing competitive pressure from the informal sector, universities are conducting major institutional restructuring, advancing, and differentiating the structure of their educational products.

Despite their positive potential, the above trends are unfolding against the background of a growing "productivity paradox" [Acemoglu et al., 2014; Ortagus et al., 2018; Polak, 2017; Krohn, 2019]: despite rapid technological development and increased coverage of education in recent decades, global economic growth rates have been declining (all the way down to negative values caused by the COVID-19 pandemic). The importance of education as a driver of technology and business process modernization at the global and national levels is increasing, especially that of entrepreneurship education (since entrepreneurship implies the creation of new companies, structures, and institutions). It is no coincidence that education's contribution to the development of entrepreneurship (including innovative entrepreneurship) is seen as a priority policy objective in Russia and other countries [Kuzminov et al., 2019; Acs et al., 2014, 2016; Bhat, Khan, 2014].

However, despite its rapid growth, the entrepreneurship education segment remains insufficiently researched in Russia and abroad alike [Nabi et al., 2017;
Sorokin et al., 2020]. The existing reputable monitoring studies tend to have formal coverage, with no in-depth content analysis and performance evaluation of initiatives designed to build entrepreneurial competencies [Sieger et al., 2018; Bosma et al., 2020]. Meanwhile World Economic Forum (WEF) experts [Wilson et al., 2009] note the importance of such informal learning offered by non-profit organizations (NPOs) in the framework of corporate programs and other continuing education formats. A variety of stakeholders show interest in innovation training, ranging from student families and businesses to the public sector. Russian education policies frequently include projects to help a wide range of people develop relevant skills to support entrepreneurship and stress the role of the informal sector in this process. ${ }^{1}$ New business formats may emerge and develop over the course of such training, potentially changing the educational ecosystem landscape, primarily in higher education. Meanwhile the steps taken to promote entrepreneurship education in the public and private sectors remain haphazard. This also applies to informal (open access) initiatives designed not only for students or employees of particular organizations but for wider audiences as well. A number of such programs have been launched in recent years under the auspices of the Russian Venture Company (RVC), the Internet Initiatives Development Fund (IIDF), and the Chamber of Commerce and Industry (CCI) for the widest possible audience, but they are just part of a rapidly emerging landscape. Even institutionally affiliated university programs remain, to a varying degree, open to everyone.

This paper attempts to compensate for the lack of knowledge and understanding of the national entrepreneurial education ecosystem. Particular attention is paid to the component least covered in the literature but a strategically important element, namely free open access informal educational initiatives aimed at a wide range of participants.

\section{Literature Review}

Analyzing the international experience of implementing open access projects in the area under consideration would help develop relevant domestic systems. In our case, it also provided the basis for developing the study methodology, including the choice of criteria applied to select and analyze observation units.

In $2009 \mathrm{WEF}$ and OECD experts conducted one of the most comprehensive studies of open access entrepreneurship education programs in the world [Wilson et al., 2009]. Their coverage, initiators, and direct and indirect performance indicators were studied. The samples were built on the basis of the internet and other open source searches, with a focus on leading universi-

${ }^{1}$ https://admtyumen.ru/files/upload/OIV/D_ipipp/5_Популяризация.pdf, accessed on 19.11.2020 (in Russian). 
ties, research organizations, and large companies. The key initiators included government agencies, businesses, NGOs, and universities engaged in entrepreneurship education, mainly for young people and with a focus on technology. This solves the social integration problem, which indirectly confirms the effectiveness of social entrepreneurship training.

In India and the US informal initiatives to develop entrepreneurial competences are often supported by NGOs. Priority is given to women, young people, and the unemployed, while coverage rates serve as performance criteria [Manimala, Thomas, 2017]. In Kazakhstan the state is the key initiator of open access entrepreneurship education projects [Bisengalieva, Smagulova, 2019].

Russian approaches to open business education and training are described in a limited number of studies focused on young people interested in such competencies. The special role of development institutions, relevant ministries, $\mathrm{R} \& \mathrm{D}$ organizations, universities, and big business is noted. The Strategic Initiatives Agency (SIA), business associations, and leading companies provide the most tangible support for entrepreneurship in the country [Freinkman, Yakovlev, 2014].

An analysis of educational projects launched with public support and reflected in the government department and university documentation revealed a lack of initiatives to promote technological entrepreneurship [Golovina et al., 2017]. Other researchers come to similar conclusions regarding government programs designed for a wide audience [Rudenko, 2019; Stromov et al., 2019; Sokolov, 2017]. A regional case study of the Tatarstan business education market revealed the low effectiveness of free government-sponsored projects and their inconsistency with other support measures [Akhmetshin, Palyakin, 2020]. The main reason is the unsatisfactory quality of business trainers' training and that of the course content.

Domestic research in the area under consideration has a pronounced focus on universities: initiatives aimed at students are analyzed and a significant lack of uniformity between them is noted [Rubin, 2016; Chepurenko, 2017]. Due to the infrastructural and institutional constraints, Russian universities' potential in promoting the development of entrepreneurship is not being fully implemented, despite the significantly increased demand [Chepurenko et al., 2019; Zobnina et al., 2019].

Russian researchers note the low level of program participation in the additional professional education sector, despite the proven positive correlation between training and economic growth in the regions [Dukhon et al., 2018]. The MOOC market is highly diversified (Coursera, Lectorium, and other platforms), but the courses' effectiveness remains low [Orlova, 2017]. However, the sample of the above study included only paid programs designed for a limited audience. We could not find publications describing the educational landscape after the launch of national projects in 2018, which might have significantly changed the situation.

This review confirms the novelty of the undertaken study of the national educational ecosystem which was analyzed through the prism of informal free educational initiatives, using Russia as an example. As noted above, this sphere rarely becomes the subject of empirical research not just in Russia but also elsewhere, despite the high demand for relevant services in the current context. The predominantly descriptive nature of the study is due to its goal: to present the main characteristics of the informal sector of the Russian entrepreneurship education market by analyzing the available open data sources. An in-depth study of specific initiatives, the evaluation of their quality and performance, identification of cause-and-effect relationships between individual factors, and the latter's effects require a separate analysis.

\section{Methodology of the Study}

The search for open access training programs was carried out between December 2020 and February 2021. The focus was on official strategic documents and websites of the leading relevant market players, first of all development institutions such as the Russian Ministry of Economic Development's Investment Policy Department, SIA, RVC, the autonomous non-profit organizations "Russia - the Country of Opportunity", "SME Corporation" JSC, "Business Environment" JSC, and "Sberbank of Russia" PJSC. An additional keyword internet search allowed the author to take into account international research results [Yan, Guan, 2019]. ${ }^{2}$ The main project selection criterion was open access to them. The following categories were excluded from the analysis: formal higher education programs (integrated into bachelor's and master's degree curricula); topics included in secondary school curricula; and paid business education and corporate training courses. One-off short-term initiatives (such as, e.g., webinars on entrepreneurship) were also disregarded, but not those aimed at specific socio-demographic or professional groups (women, self-employed, older people, etc.). The educational initiatives selected for analysis were considered open access ones if they were free-of-charge and had no requirements for applicants' affiliation with any particular organization.

Another sample building criterion was the educational component, namely that the initiative was described as an educational one by its organizers, and its description included content (in the form of methodological

\footnotetext{
The following keywords and their combinations were applied during the search: entrepreneurship education, entrepreneurship courses, entrepreneurship education courses, entrepreneurship support, entrepreneurship programs, entrepreneurship training, government entrepreneurship support program, private entrepreneurship support, social entrepreneurship, youth entrepreneurship, innovative and technology entrepreneurship, women's entrepreneurship.
} 
Table 1. Evaluation criteria for inclusion of training programmes in the sample $(N=45)$

\begin{tabular}{|l|l|l|}
\hline \multicolumn{1}{|c|}{ Criterion } & \multicolumn{1}{|c|}{ Description } & \multicolumn{1}{c|}{ Literature } \\
\hline Format & Distinguishing between face-to-face and online formats & [Hua, Ren, 2020] \\
\hline $\begin{array}{l}\text { Access to training, and } \\
\text { performance evaluation system }\end{array}$ & $\begin{array}{l}\text { Presence or absence of "entry control" and "exit performance evaluation" } \\
\text { systems. }\end{array}$ & [Nabi et al., 2017] \\
\hline Target audience & $\begin{array}{l}\text { Beginner and active entrepreneurs, various socio-demographic groups, } \\
\text { etc. }\end{array}$ & [Wilson et al., 2009] \\
\hline Initiators & Public and private sectors, universities, etc. & [Manimala, Thomas, 2017] \\
\hline Content focus of training & $\begin{array}{l}\text { Social, routine, innovation, technology entrepreneurship. The latter } \\
\text { commands the highest attention in international literature, since } \\
\text { it's expected to yiedd the highest returns. Social entrepreneurship is } \\
\text { increasingly receiving special support. }\end{array}$ & $\begin{array}{l}\text { [Sun, Li, 2020; Golovina et } \\
\text { al., 2017; Fomina, Chahine, } \\
\text { 2019] }\end{array}$ \\
\hline Relative success & Notional ranking of educational initiatives by their results. & Developed by the authors \\
\hline Source: authors. & \multicolumn{2}{l}{} \\
\hline
\end{tabular}

manuals, or special training events such as lectures or seminars). Only relatively long educational programs were taken into account. In total, 45 programs and courses were included in the sample. The evaluation criteria are presented in Table 1.

Evaluating educational programs' performance directly on the basis of publicly available data is a very difficult task. It is only possible if one understands exactly how participating in education transforms into actual business projects. One should focus on training initiatives' success indicators based on such data as coverage, best practices, various proxy indicators, and build an initial ranking using such parameters. For example, performance can be assessed as satisfactory if the coverage was sufficiently high, taking into account target audiences' characteristics and success stories.

The main limitation of our methodology is that it only allows one to use open-source data. Such sources include educational projects' descriptions and information on the courses' and programs' scope and content publicly available for preliminary review. The objectives of this study did not include an in-depth analysis of specific cases, since describing the basic parameters of the Russian landscape of informal entrepreneurship education initiatives was seen as important in itself.

\section{Empirical Analysis of Informal Entrepreneurship Education}

\section{Formats}

Twenty-eight Russian organizations offering free educational services designed to acquire entrepreneurial skills were identified. Most of the programs are offered online (40), with only a few available face-to-face (3) or in a mixed format (2). The prevalence of distance learning is in line with the global trend [Kumar et al., 2019]. In particular, there were five online university courses offered on Coursera and two each on Open Education, Universarium, and the university's own (HSE) platforms.
A small group of four programs offer a wider range of teaching methods than traditional online courses, for example, mentoring support, the interactive selection of the course structure, and remote communication with a mentor.

Interactive learning with high-technology supported interaction between teacher and students, teamwork opportunities, and so on increases the effectiveness of entrepreneurship education [Sansone, 2019]. In the Russian context, this format is rare and remains insufficiently developed in terms of methodology, at least from the point of view of information availability.

\section{Availability of Programs and the Evaluation of Results}

The identified initiatives were analyzed in terms of the presence or absence of "entry" and "exit" control systems. Access to most of them is completely open. We mean not only the absence of any charges for a wide range of applicants (all educational initiatives in the sample met this criterion), but also no assessment or testing of the entrants' knowledge or skills. Typically, just registering by stating ones' full name, e-mail address, and mobile number was sufficient. Only five out of the 45 programs had a more complex registration procedure.

Interim and final progress evaluation systems were analyzed. These are applied either in the form of examination or by asking students to defend a business project or business plan (Table 2). International educational standards require that large online platforms such as Coursera provide free access to descriptions of basic evaluation mechanisms, including an examination or more complex knowledge and competencies assessment formats. Being able to learn about such systems in advance positively affects students' accomplishments [Jimaa, 2011].

Most of such "schools" do not provide information about the principles of the systems they use to evalu- 
Table 2. Specifications of Evaluation System

\begin{tabular}{|l|l|}
\hline Type of students' progress evaluation system & $\begin{array}{l}\text { Number of } \\
\text { initiatives }\end{array}$ \\
\hline No data on specifications of evaluation system & 27 \\
\hline Examination & 14 \\
\hline Business project defence & 4 \\
\hline $\begin{array}{l}\text { * According to the initiatives' official websites. } \\
\text { Source: authors. }\end{array}$ \\
\hline
\end{tabular}

ate the results of students' learning. An exception is the "Innovation Economy and Technological Entrepreneurship" course: it holds interim exams during the training and upon completion students must defend business projects. A previous assessment of the course's effectiveness has shown that combining formal testing with project defence improves students' performance, with both these methods being equally important [Sorokin et al., 2020].

As the MOOCs example shows, simplified exit requirements (e.g., an easy test) reduce the dropout rate during training because it increases students' motivation to complete the course [Semenova, Rudakova, 2015]. However, too low requirements for the level of knowledge students must acquire during the course can lead to a situation when those who have formally completed their studies do not actually possess the relevant competencies. University projects in most cases (11 out of 12) use an examination system, which positively distinguishes them from other market players but possibly limits their coverage.

Thus, most of the initiatives do not make sufficient effort to ensure their evaluation systems are open, which can be seen as a serious limitation and a failure to meet basic standards for providing educational services.

\section{Target Audience}

In the current literature, training courses' focus on beginners or experienced businessmen frequently is chosen as the first parameter for analyzing their audience. It is based on the Global Entrepreneurship Monitor study [Bosma et al., 2020] which distinguishes nascent entrepreneurship and new business ownership, which require different program content. A similar classification is also applied in the Russian context: educational products designed for beginners offer basic entrepreneurial skills (from generating ideas to registering as an individual entrepreneur), while courses for experienced businessmen cover more complex issues such as moving business online, expanding market niches, etc.
As can be seen in Table 3, most of the training initiatives are designed for people making the first steps in business, which seems logical given that the objective is to attract new players into entrepreneurship. Each program was assessed in terms of targeting specific audiences, including those identified as priority ones in government entrepreneurship support policies. Training programs for existing businessmen, schoolchildren, people under 30 (including students), women, discharged military personnel, people over 45 , unemployed, disabled, and orphanage residents were planned to be launched in the framework of the federal project "Promoting Entrepreneurship".

Course organizers typically do not indicate their target socio-demographic groups (this was the case for 28 initiatives, or $62.2 \%$ of the total sample). Only a few projects declared a clear focus on young people (12, or $26.7 \%)$, women $(4,8.9 \%)$, and people of pre-retirement age (1). Supporting the youth is very common (12 initiatives, half of which are aimed at involving trainees in the innovation sector, such as ID Lab Skolkovo, etc.). This segment is supported by the results of student surveys: a third of the respondents consider entrepreneurship to be a promising career path [Kosharnaya, Korzh, 2020]. Three out of four courses designed to support women's entrepreneurship stress their focus on mothers on maternity leave or raising minor children (e.g., the "Entrepreneur Mom"4), which also confirms this career path's importance for more vulnerable social groups.

Only one federal initiative designed for people of preretirement age was identified: "Entrepreneurship and Practical Business Skills". However, this course does not appear to offer in-depth, specific content for the target audience. Meanwhile, as studies show, its members can become active and successful players due to their rich professional experience [Singh, de Noble, 2003]. However, this statement may not be entirely applicable to the generation who lived under the socialist system and did not gain any entrepreneurial experience over the course of the next 30 years.

No targeted offers were found for the self-employed, despite the growth in their number and the special attention paid to them in the National Project "Small and Medium-Sized Entrepreneurship, and Support for Individual Entrepreneurial Initiatives". ${ }^{5}$ Becoming selfemployed may indicate a higher willingness to establish a business, although such people's career paths differ from entrepreneurship in its traditional understanding, such as creating a start-up [Golenkova et al., 2020]. The issue of supporting the self-employed (and similar groups such as., e.g., freelancers) is relevant, but poorly studied not only in the Russian, but also in the global

\footnotetext{
${ }^{3}$ https://admtyumen.ru/files/upload/OIV/D_ipipp/5_Популяризация.pdf, accessed on 19.11.2020 (in Russian).

${ }^{4} \mathrm{https} / / /$ mama-predprinimatel.ru/, accessed on 19.11.2020 (in Russian).

https://corpmsp.ru/about/deyatelnost/natsionalnyy_proekt_maloe_i_srednee_predprinimatelstvo_i_podderzhka_individualnoy_predprinimatelskoy/, accessed on 19.11.2020 (in Russian).
} 
Table 3. Programs Ratio Designed for Nascent and Experienced Entrepreneurs $(\mathrm{N}=45)$

\begin{tabular}{|l|l|l|}
\hline \multicolumn{1}{|c|}{ Audience } & \multicolumn{1}{|c|}{$\begin{array}{c}\text { Number of } \\
\text { initiatives }\end{array}$} & $\begin{array}{c}\text { Share in total } \\
\text { number (\%) }\end{array}$ \\
\hline Nascent & 37 & 82.2 \\
\hline Experienced & 4 & 8.9 \\
\hline Nascent + Experienced & 4 & 8.9 \\
\hline Source: authors. & \multicolumn{2}{|l}{} \\
\hline
\end{tabular}

context $^{6}$ [Ozimek, 2019]. The educational programs' content is of course adapted to match the declared target audience, but inevitably only to a limited extent. For example, the Entrepreneur Mom and Women's Digital Academy projects only offer an analysis of entrepreneurial opportunities which require minimal time. No targeted open access educational initiatives were found for the former military, unemployed, and self-employed, though all these groups were classified in official documents as requiring special support.

\section{Initiators}

The initiatives of companies owned mainly by private individuals (e.g., Pepeliaev Group LLC) were naturally classified as private sector ones; if the organizers were more than $50 \%$ affiliated with the state, the project was classified as a public-private one (e.g., the initiatives offered by of Sberbank PJSC). The public sector initiatives comprised educational projects funded exclusively with public money (except those offered by universities). Initiatives implemented under the auspices of universities (which are mostly state-owned in Russia) were classified as a separate category. Russian NPOs remain at the periphery of the landscape under consideration, while in other countries they are almost the key players [Manimala, Thomas, 2017].

As shown in Table 4, most of such projects are initiated by the government, either on its own (9) or in partnership with business (14). In the first case, the SME Corporation (National SME Project) and the Russian Ministry of Economic Development are the key opera-

Table 4. Distribution of Entrepreneurship Education Programs by Organizer $(\mathrm{N}=45)$

\begin{tabular}{|l|l|l|}
\hline \multicolumn{1}{|c|}{ Initiator } & \multicolumn{1}{|c|}{$\begin{array}{c}\text { Number of } \\
\text { programmes }\end{array}$} & \multicolumn{1}{|c|}{$\begin{array}{c}\text { Share in total } \\
\text { number (\%) }\end{array}$} \\
\hline Universities & 12 & 27 \\
\hline Private sector & 10 & 22 \\
\hline $\begin{array}{l}\text { Private-public } \\
\text { partnership + NPOs }\end{array}$ & 14 & 31 \\
\hline Public sector & 9 & 20 \\
\hline Source: authors. & \\
\hline
\end{tabular}

tors. Only 10 of the identified initiatives are classified as private, with companies leading the way in social entrepreneurship training (4 out of 8 such initiatives in the sample).

A separate group comprises 12 university projects, mainly with regional status, focused on traditional "long" education (excluded from the analysis). All of them indicate the high potential for expanding the audience of universities' educational products. Thus, most of the open access initiatives are implemented either by the state or by affiliated structures in the framework of public-private partnerships, or by publicly funded universities.

\section{Focus of Training}

Authors of entrepreneurship studies often focus on the social [Dacin et al., 2011] and the innovation technology [Szabo, Herman, 2012] dimensions. We have analyzed the landscape of the identified players in terms of the social, innovation technology, and routine entrepreneurial training segments. Demand for social entrepreneurship comes from key public institutions and from potential entrepreneurs themselves [Moskovskaya et al., 2017]. The innovation technology area deserves a separate study due to its high potential for accelerating economic growth, which is important in the context of the "productivity paradox" mentioned earlier [Acs et al., 2016]. All projects that do not fall in the first two groups are focused on training in routine entrepreneurship. The initiatives were classified on the basis of available information, including statements by the project organizers themselves.

In terms of prevalence, participation in routine entrepreneurship training is twice as high as in other categories (Table 5). This can be explained by the fact that in Russia players often do not focus on increasing their profits but act out of necessity, which encourages routine rather than innovative behavior [Chepurenko et al., 2017].

Support for technological entrepreneurship is provided not only through education, but also in other formats (acceleration, infrastructure, etc.). For example, the HSE Business Incubator plays a notable role, which is at the top of the UBI Global University Accelerators ranking. Along with acceleration, the free, open access educational program "Launching a Start-up in a Month" is being implemented (included in this study's sample).

Training in social entrepreneurship is offered relatively rarely and remains the prerogative of private players. At the same time, it can be in demand as a potential revenue source. E.g., the project "Social Entrepreneurship: from Idea to Profit" declares its goal as teaching

${ }^{6}$ https://www.upwork.com/i/freelancing-in-america/, accessed on 18.06.2021. 
Table 5. Distribution of training programmes by content $(\mathrm{N}=45)$

\begin{tabular}{|l|l|l|}
\hline Entrepreneurship type & \multicolumn{1}{|c|}{$\begin{array}{c}\text { Number of } \\
\text { initiatives }\end{array}$} & $\begin{array}{c}\text { Share in total } \\
\text { number (\%) }\end{array}$ \\
\hline Social & 8 & 17.8 \\
\hline Innovation technology & 7 & 15.5 \\
\hline Routine & 30 & 66.7 \\
\hline Source: authors.
\end{tabular}

people "how to monetize a socially important business". Thus all content vectors are represented in the Russian open access entrepreneurial education initiatives landscape, albeit on different scales.

\section{Informal Education Initiatives' Results: A Ranking Attempt}

The relative performance of the training programs under consideration was evaluated (taking into account the current debate) on the basis of a wide range of available sources including data about their coverage, success stories, number of companies created by graduates, amount of capital raised, and so on. In almost all cases when coverage data was made available ( 25 training initiatives), the projects could be considered effective. However, initiatives with less than 30 participants and present on the market for no more than a year were ranked as "laggards". All projects were broken down into three groups based on their relative success. The group of leaders comprised programs that reported not only relatively high coverage, but also shared success stories or any other indirect indicators of their effectiveness ( 9 projects). The average performers group included initiatives which, according to open access data, either had a relatively high coverage, or reported other indirect success indicators (17). Laggards published no information about their coverage (or reported low coverage), no success stories, or any other indirect evidence of their effectiveness (19). Let us take a closer look at each group's main characteristics.

"Leaders". This group comprises initiatives such as SME Corporation, Entrepreneur's Alphabet, and Entrepreneurship School. The latter two projects' coverage amounted to 64,544 and 70,801 people, respectively. The Entrepreneur Mom program, despite a more modest audience $(3,938$ people), shared success stories of its participants. Members of this group have a number of common features:

- Partnership with the state. All nine initiatives directly or indirectly collaborate with public authorities, and only one (Innovation Economy and Tech- nological Entrepreneurship) is implemented by a university.

- Affiliated primarily with foreign partners. Five of the nine initiatives ( $11 \%$ of the total) participate in the BusinessClass project ${ }^{8}$ and name Google's Russian office as a partner. It was not possible to establish to what extent Google was involved in the design and implementation of the courses. The description of the course "Innovation Economy and Technological Entrepreneurship" (organized and implemented exclusively by Russian companies) also mentions collaboration with foreign experts.

- Mainly online provision. Six of the nine initiatives are implemented only online. The only exceptions are the SME Corporation projects with a vast geographic coverage (all 85 Russian regions).

- Focus on routine entrepreneurship. Eight of the nine initiatives are focused exclusively on routine entrepreneurship.

- General audience. No program in this category (except two) is designed for a specific target group.

"Average Performers". The group covers initiatives that reported either their coverage or other project success indicators, but not both. It comprises 17 programs. Of these, the federal level coverage is reported for 14, the number of covered regions for two, and data on investments attracted by students' start-ups ( 1.3 billion roubles) for one. Members in this group share several common characteristics:

- Partnership with the state. As in the case of "leaders", they are mainly affiliated with public authorities. Two of the 17 initiatives are implemented by government agencies, five by public-private partnerships, nine by universities, and a single one by a private provider.

- High share of university initiatives. Nine projects of the 17 are implemented by universities (exclusively online).

- General profile. These initiatives are designed for teaching not only routine (9 out of 17), but also social (2) and technological entrepreneurship (6).

- Specific audience. More than half of the 17 initiatives (9) explicitly define their target audience: two are designed for women and seven for young people. Unlike the "leaders", this group is more likely to segment their audience.

"Laggards". Projects in this group do not publish information on any of their performance indicators, be it coverage or other parameters, or the available data clearly indicates their poor performance and low de-

https://бизнесюгры.pф/support/informatsiya-dlya-subektov-kreativnykh-industriy/obrazovatelnye-onlayn-meropriyatiya/, accessed on 18.06.2021 (in Russian).

${ }^{8}$ https://business-class.pro/, accessed on 18.06.2021. 
mand for them (three initiatives covering less than 30 people each). Their main characteristics are as follows:

- Low affiliation with the state. Seven of the 19 programs are owned by private companies (only 10 such initiatives in the whole sample). The lack of government support may explain the problems with promoting these projects.

- Low involvement of educational organizations. Only two of these initiatives were launched by universities (note that in the whole sample there are 12 such projects). Outsider projects are often initiated by organizations whose main activities are unrelated to education. The lack of relevant experience and competencies adversely affects the programs' or courses' content.

- Insufficiently transparent progress evaluation system. Sixteen of the 19 programs do not describe the mechanisms they use to evaluate students' progress.

- Priority of social entrepreneurship. Six of the 19 initiatives are focused on training in social entrepreneurship ( 8 in the whole sample of 45 programs).

\section{Conclusion}

This paper attempted to make an initial assessment of the current landscape of open access entrepreneurship education initiatives in Russia by using the "unbundling" concept and taking into account the contemporary science and technology development trends.

The informal sector represents an important, but insufficiently researched area of the rapidly growing national entrepreneurship education ecosystem, which is taking over an increasing share of the traditional formal education segment. This study identified 12 cases of universities offering alternative entrepreneurship education products with a flexible structure, designed for a wide audience. However, universities do not dominate the market in question. Initiatives offered by new players, including the private sector, non-profit organizations, and state development institutions act not as supplements, but rather as alternatives to traditional "long" professional education programs. This erosion of universities' monopoly will allow people to more ef- fectively accomplish the objectives associated with the accelerated modernization of educational technologies and business processes.

Entrepreneurship training makes a special contribution to the country's socioeconomic development. However, the formal education system is not keeping pace with its growth. First of all, this applies to universities, with their cumbersome system of lengthy bureaucratic approval procedures. The proposals of new educational service providers, including large companies (Sberbank) and development institutions (RVC, IIDF) emerged in response to this sluggishness of traditional higher education organizations.

Universities' cooperation with public and private partners in the informal sector of entrepreneurship education must be stepped up. Universities can act as operators in launching and implementing such projects, in particular as competence centers to design course content and progress evaluation systems. Possible recommendations to improve open access entrepreneurship education initiatives in Russia include the following:

1. Introducing a system for evaluating students' progress during and after the training, which is adequately supported by the necessary resources, equipment, and sufficiently qualified personnel to implement advanced teaching practices.

2. Monitoring education productivity, including success stories, e.g., in the form of tracking graduates' career paths.

3. Extending targeted programs designed for specific audiences, including in the scope of the National SME Project (e.g., for the unemployed) and more precisely adapting them to match specific characteristics and requirements of relevant groups (e.g., young mothers or older people).

4. Increasing the range of open access initiatives in training technology and innovation entrepreneurs, which have the highest potential to contribute to economic growth but remain underrepresented in the Russian context.

The paper was produced with the support of the Russian Ministry of Science and Higher Education grant No. 075-152020-928.

\section{References}

Acemoglu D., Autor D., Dorn D., Hanson G., Price B. (2014) Return of the Solow Paradox? IT, Productivity, and Employment in US Manufacturing. American Economic Review, 104 (5), 394-399. DOI:10.1257/aer.104.5.394.

Acs Z.J., Audretsch D.B., Lehmann E.E., Licht G. (2016) National systems of entrepreneurship. Small Business Economics, 46(4), 527-535. DOI: 10.1007/s11187-016-9705-1.

Acs Z.J., Autio E., Szerb L. (2014) National systems of entrepreneurship: Measurement issues and policy implications. Research Policy, 43, 476-494. DOI: 10.1016/j.respol.2013.08.016.

Akhmetshin R.M., Palyakin R.B. (2021) Challenges of Entrepreneurship Education in the Republic of Tatarstan. In: Engineering Economics: Decisions and Solutions from Eurasian Perspective, Engineering Economics Week 2020 (eds. S. Ashmarina, V. Mantulenko, M. Vochozka), Lecture Notes in Networks and Systems, vol. 139, Heidelberg, Dordrecht, London, New York: Springer, pp. 633-639. https://doi.org/10.1007/978-3-030-53277-2_75. 
Bandyopadhyay S., Bardhan A., Dey P., Bhattacharyya S. (2021) Bridging the Education Divide Using Social Technologies, Singapore: Springer. https://doi.org/10.1007/978-981-33-6738-8_3

Bhat S., Khan R. (2014) Entrepreneurship Education Ecosystem: An Assessment Study of J\&K State. International Journal of Economics, Commerce and Management, 2(4), 1-8. https://papers.ssrn.com/sol3/papers.cfm?abstract_id=2426797, accessed 06.08.2021.

Bisengalieva A.A., Smagulova N.T. (2019) Analysis of the state of bisiness education in modern conditions. Issues in Contemporary Science and Education, 4 (137), 29-32 (in Russ.).

Bosma N., Hill S., Ionescu-Somers A., Kelley D., Levie J., Tarnawa A. (2020) Global Entrepreneurship Monitor 2019-2020 Global Report, London: Global Entrepreneurship Research Association.

Brush C.G. (2014) Exploring the concept of an entrepreneurship education ecosystem. In: Innovative pathways for university entrepreneurship in the 21st century (eds. S. Hoskinson, D.F. Kuratko), Bingley: Emerald Group Publishing Limited, pp. 25-39.

Chepurenko A. (2017) How and Why Entrepreneurship Should Be Taught to Students: Polemical Notes. Voprosy Obrazovaniya / Educational Studies Moscow, 3, 250-276. DOI: 10.17323/1814-9545-2017-3-250-276 (in Russ.).

Chepurenko A., Kristalova M., Wyrvich M. (2019) Historical and Institutional Determinants of Universities' Role in Fostering Entrepreneurship. Foresight and STI Governance, 13(4), 48-59. DOI: 10.17323/2500-2597.2019.4.48.59 (in Russ.).

Chepurenko A., Popovskaya E., Obraztsova O. (2017) Cross-regional Variations in the Motivation of Early-Stage Entrepreneurial Activity in Russia: Determining Factors. In: Entrepreneurship in Transition Economies (eds. A. Sauka, A. Chepurenko), Heidelberg, Dordrecht, London, New York: Springer, pp. 315-342.

Dacin M.T., Dacin P.A., Tracey P. (2011) Social entrepreneurship: A critique and future directions. Organisation Science, 22(5), 1203-1213. https://doi.org/10.1287/orsc. 1100.0620

Dukhon A., Zinkovsky K., Obraztsova O., Chepurenko A. (2018) How Entrepreneurship Education Programmes Affect the Development of Small Businesses in Russia: Empirical Analysis in Regional Contexts. Voprosy Obrazovaniya / Educational Studies Moscow. 2, 139-172. DOI: 10.17323/1814-9545-2018-2-139-172 (in Russ.).

Fomina Y., Chahine T. (2019) Responsible People Palgrave Studies in Governance, Leadership and Responsibility. In: Social Entrepreneurship Factors of Success and Failure in the Omsk Region of Russia (eds. F. Farache, G. Grigore, A. Stancu, D. McQueen), London: Palgrave Macmillan, pp. 89-111. https://doi.org/10.1007/978-3-030-10740-6_5

Freinkman L., Yakovlev A. (2014) Agency for Strategic Initiatives as a New Type of Development Institution. Voprosy Ekonomiki, 6, 18-39. https://doi.org/10.32609/0042-8736-2014-6-18-39

Golenkova Z.T., Goliusova Y.V., Gorina T.I. (2020) Sociological portrait of the self-employed in contemporary Russia. RUDN Journal of Sociology, 20(4), 821-836. https://doi.org/10.22363/2313-2272-2020-20-4-821-836 (in Russ.).

Golovina T., Merkulov P., Polyanin A. (2017) Strategic Vectors of the Development of the State Support of Youth Entrepreneurship in Russia. Ekonomicheskaya Politika, 12(5), 42-61 (in Russ.).

Hua S., Ren Z. (2020) “Online+ Offline” Course Teaching Based on Case Teaching Method: A Case Study of Entrepreneurship Education Course. International Journal of Emerging Technologies in Learning, 15(10), 69-85.

Ivancheva M.P., Swartz R., Morris N.P., Walji S., Swinnerton B.J., Coop T., Czerniewicz L. (2020) Conflicting logics of online higher education. British Journal of Sociology of Education, 41(5), 608-625. https://doi.org/10.1080/01425692.2020.1784707

Jimaa S. (2011) The impact of assessment on students learning. Procedia-Social and Behavioral Sciences, 28, 718-721. https:// doi.org/10.1016/j.sbspro.2011.11.133

Kosharnaya G.B., Korzh N.V. (2020) Social well-being of the student youth (regional aspect). RUDN Journal of Sociology, 20(4), 905-918. DOI: 10.22363/2313-2272-2020-20-4-905-918 (in Russ.).

Krohn G.A. (2019) A Note on "Puzzles, Paradoxes, and Regularities: Cyclical and Structural Productivity in the United States (1950-2005). Review of Radical Political Economics, 51(1), 158-163. https://doi.org/10.1177\%2F0486613417720774

Kulik E.Yu. (ed.) (2018) eLearning Stakeholders and Researchers Summit 2018: Proceedings of the International Conference, Moscow: HSE.

Kumar P., Kumar A., Palvia S., Verma S. (2019) Online business education research: Systematic analysis and a conceptual model. The International Journal of Management Education, 17(1), 26-35. https://doi.org/10.1016/j.ijme.2018.11.002

Kuzminov Ya., Sorokin P., Froumin I. (2019) Generic and Specific Skills as Components of Human Capital: New Challenges for Education Theory and Practice. Foresight and STI Governance. 13(2), 19-41. DOI: 10.17323/2500-2597.2019.2.19.41.

Manimala M.J., Thomas P. (2017) Entrepreneurship Education: Innovations and Best Practices, Singapore: Springer. https://doi. org/10.1007/978-981-10-3319-3_1

McCowan T. (2017) Higher education, unbundling, and the end of the university as we know it. Oxford Review of Education, 43(6), 733-748. https://doi.org/10.1080/03054985.2017.1343712

Moskovskaya A.A., Berendyaev A.A., Moskvina A.Yu. (2017) Between social and economic good: Conflicting projects of legitimation of social entrepreneurship in Russia. Monitoring of Public Opinion: Economic and Social Changes, 6, 31-51. DOI: 10.14515/monitoring.2017.6.02 (in Russ.).

Nabi G., Liñán F., Fayolle A., Krueger N., Walmsley A. (2017) The impact of entrepreneurship education in higher education: A systematic review and research agenda. Academy of Management Learning \& Education, 16(2), 277-299. https://doi. org/10.5465/amle.2015.0026

Orlova E.Yu. (2017) The use of massive open online courses for teaching the basics of entrepreneurship in technical university. Economics and Quality of Communication Systems, 1 (3), 94-98 (in Russ.).

Ortagus J.C., Kramer D.A., Umbricht M.R. (2018) Exploring the IT Productivity Paradox in Higher Education: The Influence of IT Funding on Institutional Productivity

. Journal of Higher Education 89(2), 129-152.

Polak P. (2017) The productivity paradox: A meta-analysis. Information Economics and Policy, 38, 38-54. 
Rubin Y.B. (2016) Creation of graduates' entrepreneurial competencies within the educational area of baccalaureate. Higher Education in Russia, 1, 7-20 (in Russ.).

Rudenko L.G. (2019) Formation of system of support of development of small youth business. Vestnik Universiteta, 3, 197113. https://doi.org/10.26425/1816-4277-2019-3-107-113 (in Russ.).

Sansone G., Battaglia D., Landoni P., Paolucci E. (2019) Academic spinoffs: The role of entrepreneurship education. International Entrepreneurship and Management Journal, 17, 369-399. https://doi.org/10.1007/s11365-019-00601-9

Semenova T.V., Rudakova L.M. (2015) Barriers when taking massive open online courses (MOOCs). Monitoring of Public Opinion: Economic and Social Changes, 3, 35-48. https://doi.org/10.14515/monitoring.2015.3.04 (in Russ.).

Sieger P., Fueglistaller U., Zellweger T., Braun I. (2018) Global Student Entrepreneurship 2018: Insights From 54 Countries, St. Gallen, Bern: KMU-HSG/IMU.

Singh G., DeNoble A. (2003) Early retirees as the next generation of entrepreneurs. Entrepreneurship Theory and Practice, 27(3), 207-226. https://doi.org/10.1111/1540-8520.t01-1-00001

Sokolov V.V. (2017) Youth business in system of priorities of state youth policy: state and support mechanisms. Central Russian Journal of Social Sciences, 12(4), 48-55 (in Russ.).

Sorokin P.S., Chernenko S.E., Povalko A.B. (2020) Teaching entrepreneurship in universities in Russia and the world: Why, how and with what results?, Moscow: HSE. https://publications.hse.ru/mirror/pubs/share/direct/380038633.pdf, accessed 06/17/2021 (in Russ.).

Stromov V.Yu., Sysoyev P.V., Zavyalov V.V. (2019). Cluster Approach to the Development of Youth Entrepreneurship in Classical University. Higher Education in Russia, 28(7), 102-109. https://doi.org/10.31992/0869-3617-2019-28-7-102-109 (in Russ.).

Sun D., Li S., Xu X. (2020) Analysis of reform and development strategies of China's Internet innovation and entrepreneurship education. Entrepreneurship Education, 3(1), 77-93. https://doi.org/10.1007/s41959-020-00024-6

Szabo Z.K., Herman E. (2012) Innovative entrepreneurship for economic development in EU. Procedia Economics and Finance, 3, 268-275. https://doi.org/10.1016/S2212-5671(12)00151-7

Wilson K.E., Vyakarnam S., Volkmann C., Mariotti S., Rabuzzi D. (2009) Educating the next wave of entrepreneurs: Unlocking entrepreneurial capabilities to meet the global challenges of the 21st century, Geneva: World Economic Forum.

Yan Y., Guan J. (2019) Entrepreneurial ecosystem, entrepreneurial rate and innovation: The moderating role of internet attention. International Entrepreneurship and Management Journal, 15(2), 625-650. DOI: 10.1007/s11365-018-0493-8.

Zobnina M., Korotkov A., Rozhkov A. (2019) Structure, Challenges and Opportunities for Development of Entrepreneurial Education in Russian Universities. Foresight and STI Governance, 13(4), 69-81. DOI: 10.17323/2500-2597.2019.4.69.81 